This item was submitted to Loughborough's Research Repository by the author.

Items in Figshare are protected by copyright, with all rights reserved, unless otherwise indicated.

\title{
Identifying tensions in the servitized value chain
}

PLEASE CITE THE PUBLISHED VERSION

http://www.tandfonline.com/doi/full/10.1080/08956308.2016.1208042

\section{PUBLISHER}

Taylor \& Francis

\section{VERSION}

AM (Accepted Manuscript)

\section{PUBLISHER STATEMENT}

This work is made available according to the conditions of the Creative Commons Attribution-NonCommercialNoDerivatives 4.0 International (CC BY-NC-ND 4.0) licence. Full details of this licence are available at: https://creativecommons.org/licenses/by-nc-nd/4.0/

\section{LICENCE}

CC BY-NC-ND 4.0

\section{REPOSITORY RECORD}

Burton, Jamie, Victoria Story, Judy Zolkiewski, Chris Raddats, Tim Baines, and Dominic Medway. 2019. "Identifying Tensions in the Servitized Value Chain". figshare. https://hdl.handle.net/2134/22543. 


\section{Identifying Tensions in the Servitized Value Chain}

Jamie Burton, Vicky Story, Judy Zolkiewski, Chris Raddats, Tim S. Baines, and Dominic Medway

This is a pre-print (non-publisher's document). Please cite the published article:

Burton, J., Story, V., Zolkiewski, J., Raddats, C., Baines, T.S., Medway, D. (forthcoming) Identifying Tensions in the Servitized Value Chain, Research-Technology Management

Jamie Burton is a senior lecturer in marketing and Research Director of the practitionerfacing Customer Management Leadership Group at Alliance Manchester Business School. His research interests include customer management and services marketing. Jamie.Burton@manchester.ac.uk

Vicky Story is a reader in marketing and retailing at Loughborough University, UK. Her research interests include innovation and marketing strategy. V.M.Story@lboro.ac.uk

Judy Zolkiewski is Associate Head of Division (MSM) for Teaching at Alliance Manchester Business School at the University of Manchester. Judy's research focuses on understanding the operation of business-to-business marketing and purchasing. Judy.Zolkiewski@manchester.ac.uk

Chris Raddats is a lecturer in marketing and operations at the University of Liverpool, UK. He specializes in the study of servitization. C.Raddats@liverpool.ac.uk

Tim Baines, director of the Aston Centre for Servitization Research and Practice, is a leading authority on servitization and advanced services who works with both global and local manufacturing companies to help transform businesses. T.Baines@aston.ac.uk

Dominic Medway, professor of marketing at the Institute of Place Management, Manchester Metropolitan University, UK, is a specialist in place marketing and management. D.Medway@mmu.ac.uk

Overview: Servitization is recognized as an opportunity for manufacturing firms to harvest additional value by accessing new sources of revenue and expanding their reach up and down the value chain. It is a network activity, as it involves not just the servitizing firm but actors across the firm's ecosystem. Most studies argue that servitization creates value for all network actors. However, service innovation activities may also result in the 
firm appropriating value from other actors, creating tensions in the network. Those tensions can undermine servitization efforts and destroy value for all participants. To avoid this outcome, firms must anticipate and defuse or manage tensions to create cooperative relationships with value chain partners. Through a series of semi-structured interviews with key actors at servitizing firms and their customers and intermediaries, we identified specific types and sources of tensions in the servitization process and explored how they might be mitigated or managed.

Keywords: Servitization; Business model innovation; Service innovation; Value chain

Tension - between people and within and between groups and organizations-are a part of every relationships. In business contexts, such tensions may lead key actors to actively resist ideas, initiatives, and processes developed by others. Despite the pervasiveness of relational tensions, however, researchers rarely explore their role in the strategic evolution of organizations. Rather, the majority of research adopts the perspective of the organization implementing a particular strategy, considering its actions and likely outcomes and paying scant attention to the responses of other actors who might be affected by these initiatives-or the effects of their responses.

These tensions may be particularly important in the domain of servitization, as the process of moving from a product to a services focus necessarily involves not just the manufacturer but its entire value chain. Thus, the effects of servitization may ripple across a manufacturer's network, as the focal organization reorganizes its resources, takes on elements once left to other actors, and sheds other activities. To develop a comprehensive picture of servitization processes and outcomes, then, requires taking a network perspective, considering reactions and responses across the value chain.

Because tensions operate between actors - whether those actors are individuals, groups, or organizations - servitization is most effectively studied through a multi-actor lens, one that considers the transformation not just from the perspective of the focal organization, but from the perspectives of all of the parties involved. Looking at the process in this way both illuminates the tensions likely to emerge and suggests strategic responses to them, helping managers pinpoint where to look for tensions within their network-and head them off before they destroy value or derail the process altogether.

\section{Servitization in a Network Context}

Servitization, generally defined as a manufacturer's shift in focus from making products to offering services that support customers' operations, is widely recognized as a mechanism to achieve revenue growth and generate increased profits (Baines et al. 2009). However, researchers have also demonstrated these outcomes are not guaranteed. Thus, firms attempting servitization may see mixed financial outcomes and struggle to realize even modest benefits (Oliva and Kallenberg 2003; Reinartz and Ulaga 2008).

Such mixed results are testament to the complexity of the servitization process and the efforts required to develop and deliver these services. One source of such complexity is the need to involve actors up and down the firm's value chain and, at the same time, to appropriate additional mechanisms of value creation. Successful servitization requires 
manufacturers to develop a range of capabilities involving a network of actors across the value chain (Raddats and Burton 2014), both upstream (other manufacturers and suppliers) and downstream (customers and end users). Gleaning value from servitization also requires appropriation of activity-specific resources from suppliers and intermediaries, in order to acquire technical expertise or physical service infrastructure, either temporarily or permanently (Gertler 1995). This appropriation can destabilize the value chain in both directions: Manufacturers taking over processes that other supply chain actors had previously performed can lead to overlap, duplication, or redundancy in processes and individual activities (Spring and Araujo 2013), and taking over customer processes can require the development of new capabilities (Paiola et al. 2013) to integrate products or processes from multiple contributors (Davies, Brady, and Hobday 2007).

Given these needs, manufacturers must work together with network partners to assure that servitization delivers an improved value outcome (Story et al. 2016). Cooperation across the network is particularly important for the development and delivery of advanced services — offerings focused on providing availability or capability rather than tangible products. Advanced services, which are also known as use- or results-oriented product-service systems (Tukker 2004), are understood as representing a "relationship over [an] extended life-cycle" and feature "extended responsibilities and regular revenue payments” (Baines and Lightfoot 2013, p. 22). Advanced services require the coordinated activity of a network of actors, both internal and external to the service provider, to create value (Kowalkowski, Kindström, and Witell 2011). Delivering advanced services in a way that creates value requires interaction between multiple actors, jointly applied technical expertise, and co-deployment of physical resources (Salonen and Jaakkola 2015).

To accommodate these requirements, manufacturers must instigate changes in activities, processes, and approach, both internally and with and for other actors, at the organizational, group, and individual levels. These changes may include adjustments in how activities — and the value associated with them — are allocated. Such adjustments inevitably reshape relationships between network actors, often in ways that create tension. For instance, as a servitizing manufacturer develops expanded capabilities and moves into areas of expertise historically provided by other actors, those other actors may feel their value-creating assets are under threat and move to defend their place in the value chain. This action could lead to power-play conflicts (Zolkiewski, Burton, and Stratoudaki 2008) and reduced network participants' willingness to engage in value cocreation.

Such conflicts create relational tensions that can hamper the evolution of service innovation activities and limit or destroy the value that would otherwise be created or captured by service offerings. Left unaddressed, these tensions could destroy value for all actors, especially if actors respond to the tension by attempting to defend or gain power that they then use to block servitization processes. Therefore, manufacturers undertaking servitization must anticipate, identify, defuse, and respond to these tensions if their efforts are to be successful. Because previous work has primarily focused on servitization from the perspective of the servitizing firm, it has neither identified what these tensions are nor, crucially, suggested how actors might respond to them and servitizing firms 
might proactively manage them. As a result, there is little understanding of the tensions that might develop between network actors during servitization.

\section{Study Design}

To answer these questions, we undertook an exploratory, qualitative study, using semistructured interviews with senior executives at servitizing firms as well as at strategic customer and supplier firms for each participating focal firm. Data were gathered from five participating manufacturers that provide advanced services across five sectors: defense (DefCo), transport (TransCo), chemicals (ChemCo), precision engineering (PECo), and power (PowerCo). Participating companies were selected for their sustained track records of successful technological innovation. We also conducted interviews at three customer organizations - in the power (PowerCust), education (EduCust), and government (GovCust) sectors - and one intermediary organization, in the transport industry (TransInt). Interviews were conducted with senior executives, including managing directors, operations/supply chain directors, and key sales, service, and strategy personnel. These key strategic personnel were chosen based on their ability to provide informed insight regarding the participating manufacturers’ servitization processes.

Using a technique called "template analysis" (King 2004), we first developed a template of initial themes regarding the types of tensions that might occur between actors involved in servitization; these themes were drawn from the literature and were used to help steer the interviews, without limiting interviewees to the specific themes identified in the template. We conducted a total of 13 interviews, 9 at focal firms, 3 at customer firms, and 1 at the intermediary. The interviews, each of which lasted about an hour, focused on the process of servitization, the tensions that arose with other actors during the development and delivery of advanced services, and responses to those tensions. The interviews were all recorded, transcribed, and thematically coded. As the analysis of the transcripts continued, the list of themes initially captured in the template was refined and developed, leading ultimately to a final list of tensions and, where they were captured in the narratives, actors' responses (or suggested responses) to these tensions.

\section{Identification of Tensions and Responses}

Our study revealed a number of tensions, both between organizational actors and between groups and individual actors within those organizations. Tensions appear to be particularly relevant when manufacturers move to offering advanced services, as opposed to more traditional service offerings, such as simple service contracts. As the servitization process develops, and the implications for other actors in terms of resources, costs, and risks become apparent, tensions develop. In response, both focal firms and others in the value network may take a variety of actions, including investing in new resources or capabilities, building stronger intra- or interfirm relationships, intensifying the focus on innovation to ensure continued competitive advantage, and communicating a strong services vision that can be shared across the network and agreed on by all network actors.

Our analysis identified 19 types of tensions, which we categorized into five broad groups (Table 1): 
- Direct Challenge to Expertise, emerging from perceived direct threats to an actor's area of expertise;

- Pressure to Learn, emerging from the reluctance of the manufacturer's employees to embrace new capabilities needed to support servitization;

- Cost-Focused Challenges, emerging from challenges to service innovation based on the cost of extending expertise and resources;

- Process-Change Risk Aversion, emerging from actors' reluctance to challenge other actors due to a perceived personal risk of doing so; and

- External Actor Impacts on Value Creation, emerging from manufacturers' need to rely on and interact with other actors to deliver advanced services.

Tensions may occur both within and between organizations and they may occur at the level of individuals or groups or at the organizational level.

Table 1.-Types of tensions that may emerge in servitization

\begin{tabular}{|c|c|c|c|}
\hline Tensions & Actor 1 & Actor 2 & Description \\
\hline \multicolumn{4}{|c|}{ Group I. Direct Challenge to Expertise } \\
\hline $\begin{array}{l}\text { 1. Fear of } \\
\text { cannibalizing product } \\
\text { markets }\end{array}$ & $\begin{array}{l}\text { Manufacturer's } \\
\text { product sales } \\
\text { team }\end{array}$ & $\begin{array}{l}\text { Manufacturer's } \\
\text { service staff or } \\
\text { service strategic } \\
\text { business unit } \\
\text { (SBU) }\end{array}$ & $\begin{array}{l}\text { Product sales team may } \\
\text { fear that services } \\
\text { competition in its markets } \\
\text { may cause customers to } \\
\text { stop buying products. }\end{array}$ \\
\hline $\begin{array}{l}\text { 2. Competitors } \\
\text { poaching skilled } \\
\text { employees }\end{array}$ & $\begin{array}{l}\text { Manufacturer's } \\
\text { human } \\
\text { resources }\end{array}$ & Competitors & $\begin{array}{l}\text { Competitors hire away } \\
\text { employees trained to } \\
\text { provide services. }\end{array}$ \\
\hline $\begin{array}{l}\text { 3. Customer resistance } \\
\text { to purchasing services }\end{array}$ & $\begin{array}{l}\text { Customer’s } \\
\text { procurement } \\
\text { team }\end{array}$ & $\begin{array}{l}\text { Manufacturer's } \\
\text { service SBU }\end{array}$ & $\begin{array}{l}\text { Customers do not buy } \\
\text { service offerings because } \\
\text { they think they can } \\
\text { service products more } \\
\text { cheaply using their own } \\
\text { resources. }\end{array}$ \\
\hline $\begin{array}{l}\text { 4. Employee efforts to } \\
\text { protect personal status }\end{array}$ & $\begin{array}{l}\text { Customer's } \\
\text { employees }\end{array}$ & $\begin{array}{l}\text { Customer's } \\
\text { managers and/or } \\
\text { Manufacturer's } \\
\text { service SBU }\end{array}$ & $\begin{array}{l}\text { Customer employees fear } \\
\text { loss of status related to } \\
\text { domain expertise and so } \\
\text { resist use of } \\
\text { manufacturer's services. }\end{array}$ \\
\hline $\begin{array}{l}\text { 5. Fear of expertise } \\
\text { loss }\end{array}$ & $\begin{array}{l}\text { Customer’s } \\
\text { senior } \\
\text { managers }\end{array}$ & $\begin{array}{l}\text { Manufacturer's } \\
\text { service SBU }\end{array}$ & $\begin{array}{l}\text { Customers resist external } \\
\text { services out of fear of } \\
\text { losing internal expertise } \\
\text { and staff with critical skill } \\
\text { sets. }\end{array}$ \\
\hline 6. Increased & Manufacturer & Competitors & Traditional product \\
\hline
\end{tabular}




\begin{tabular}{|c|c|c|c|}
\hline $\begin{array}{l}\text { competition in product } \\
\text { and services markets }\end{array}$ & & & $\begin{array}{l}\text { markets shrink, increasing } \\
\text { competition and thus } \\
\text { tension in services } \\
\text { markets. }\end{array}$ \\
\hline $\begin{array}{l}\text { 7. Increased local } \\
\text { competition }\end{array}$ & Manufacturer & Competitors & $\begin{array}{l}\text { Local, smaller } \\
\text { competitors, who have } \\
\text { location advantages, start } \\
\text { to duplicate } \\
\text { manufacturers' new } \\
\text { services offerings. }\end{array}$ \\
\hline $\begin{array}{l}\text { 8. Customer pressure } \\
\text { for skills transfer }\end{array}$ & Manufacturer & Customer & $\begin{array}{l}\text { As customers gain } \\
\text { experience, they demand } \\
\text { to learn how to self- } \\
\text { service new products in } \\
\text { an effort to bring } \\
\text { previously servitized } \\
\text { activities back inside their } \\
\text { organizations. }\end{array}$ \\
\hline $\begin{array}{l}9 . \\
\text { Legislative/regulatory } \\
\text { barriers to territorial } \\
\text { activity }\end{array}$ & Manufacturer & Government(s) & $\begin{array}{l}\text { Governmental entities } \\
\text { create rules or legislation } \\
\text { hampering service } \\
\text { delivery. }\end{array}$ \\
\hline \multicolumn{4}{|c|}{ Group II: Pressure to Learn } \\
\hline $\begin{array}{l}\text { 10. Reluctance to } \\
\text { abandon entrenched } \\
\text { product culture }\end{array}$ & $\begin{array}{l}\text { Manufacturer's } \\
\text { employee }\end{array}$ & $\begin{array}{l}\text { Manufacturer’s } \\
\text { manager }\end{array}$ & $\begin{array}{l}\text { Product-expert employees } \\
\text { are reluctant to step } \\
\text { outside their comfort } \\
\text { zones, accept process } \\
\text { changes, and engage in } \\
\text { service activities. }\end{array}$ \\
\hline $\begin{array}{l}\text { 11. Employee } \\
\text { reluctance to acquire } \\
\text { new skills to support } \\
\text { services }\end{array}$ & $\begin{array}{l}\text { Manufacturer's } \\
\text { employee }\end{array}$ & $\begin{array}{l}\text { Manufacturer's } \\
\text { manager }\end{array}$ & $\begin{array}{l}\text { Employees are reluctant } \\
\text { to learn new service- } \\
\text { related skills. }\end{array}$ \\
\hline \multicolumn{4}{|c|}{ Group III: Cost-Focused Challenges } \\
\hline $\begin{array}{l}\text { 12. Managers' } \\
\text { avoidance of } \\
\text { intermediaries' } \\
\text { services markets }\end{array}$ & $\begin{array}{l}\text { Manufacturer's } \\
\text { senior } \\
\text { managers }\end{array}$ & $\begin{array}{l}\text { Manufacturer's } \\
\text { service staff or } \\
\text { service SBU }\end{array}$ & $\begin{array}{l}\text { Senior managers make } \\
\text { strategic decisions not to } \\
\text { enter particular service } \\
\text { markets to avoid affecting } \\
\text { intermediaries and facing } \\
\text { costs of ending } \\
\text { established supply-chain } \\
\text { relationships. }\end{array}$ \\
\hline $\begin{array}{l}\text { 13. Focus on cost } \\
\text { control }\end{array}$ & $\begin{array}{l}\text { Manufacturer's } \\
\text { finance } \\
\text { employees }\end{array}$ & $\begin{array}{l}\text { Manufacturer's } \\
\text { service staff or } \\
\text { service SBU }\end{array}$ & $\begin{array}{l}\text { Finance staff members } \\
\text { restrict investment in } \\
\text { services capabilities }\end{array}$ \\
\hline
\end{tabular}




\begin{tabular}{|c|c|c|c|}
\hline & & & within given periods. \\
\hline $\begin{array}{l}\text { 14. Resistance to } \\
\text { manufacturer demands } \\
\text { for increased } \\
\text { geographic coverage }\end{array}$ & Manufacturer & Intermediary & $\begin{array}{l}\text { Manufacturers demand } \\
\text { that intermediaries and } \\
\text { suppliers provide a more } \\
\text { comprehensive service } \\
\text { network to support } \\
\text { integrated advanced } \\
\text { services offerings. }\end{array}$ \\
\hline $\begin{array}{l}\text { 15. Customer demand } \\
\text { for life extension } \\
\text { support }\end{array}$ & Manufacturer & Customer & $\begin{array}{l}\text { Customer pressure } \\
\text { manufacturer to share } \\
\text { costs of maintaining } \\
\text { product infrastructure to } \\
\text { retain the service contract } \\
\text { and perhaps even avoid } \\
\text { the customer shutting } \\
\text { down the infrastructure } \\
\text { altogether. }\end{array}$ \\
\hline $\begin{array}{l}\text { 16. Interference of } \\
\text { existing systems with } \\
\text { new services purchases }\end{array}$ & Customer & Manufacturer & $\begin{array}{l}\text { Customer's IT systems } \\
\text { prevent adoption of } \\
\text { software-based service } \\
\text { provision. }\end{array}$ \\
\hline \multicolumn{4}{|c|}{ Group IV: Process-Change Risk Aversion } \\
\hline $\begin{array}{l}\text { 17. Actor reluctance to } \\
\text { influence activities of } \\
\text { other actors }\end{array}$ & $\begin{array}{l}\text { Customer's } \\
\text { procurement } \\
\text { employee }\end{array}$ & $\begin{array}{l}\text { Customer's } \\
\text { employees }\end{array}$ & $\begin{array}{l}\text { Younger employees who } \\
\text { lack status may avoid } \\
\text { pushing through changes } \\
\text { that might lead other staff } \\
\text { members to challenge } \\
\text { them or endanger their } \\
\text { role. }\end{array}$ \\
\hline \multicolumn{4}{|c|}{ Group V: External Actor Impacts on Value Creation } \\
\hline $\begin{array}{l}\text { 18. Dependence on } \\
\text { third-party capabilities } \\
\text { to succeed in market }\end{array}$ & Manufacturer & Intermediary & $\begin{array}{l}\text { Performance of service } \\
\text { delivery, and thus } \\
\text { creation of value, depends } \\
\text { on performance of third } \\
\text { parties, who may not } \\
\text { deliver consistently. }\end{array}$ \\
\hline $\begin{array}{l}\text { 19. Fluctuations in } \\
\text { customer willingness } \\
\text { to engage in value co- } \\
\text { creation activity }\end{array}$ & Manufacturer & Customer & $\begin{array}{l}\text { Customers may reduce } \\
\text { information flows to } \\
\text { manufacturers or } \\
\text { withdraw from co- } \\
\text { creation efforts during } \\
\text { contract tender periods, } \\
\text { reducing opportunities for } \\
\text { co-creation of value. }\end{array}$ \\
\hline
\end{tabular}


Tensions can be internal (for instance, those generated by employees' or groups' fear that servitization represents a threat to their established domains of activity, and hence to their status [tension 4]) or external (for instance, tensions generated by manufacturer's hiring away of key resources or by increased competition [tensions 2, 6, 7]). Except regulatory tensions (tension 9), all tensions operate at the micro-environmental level, confined to the servitizing firm's value network. Internal tensions may arise between individuals or groups in the servitizing firm or within other organizations in the firm's value network; we identified seven internal tensions, between individuals, between groups and individuals, and between groups within an organization (Figure 1). External tensions may involve the manufacturer and external customers, intermediaries, or governmental bodies; we identified 13 interorganizational tensions between organizational actors (Figure 2). One tension - tension 4, protection of personal activity — may occur both within and across organizational actors, depending on whether it operates wholly within the customer organization or between the customer organization and the manufacturer's organization.

\section{Figure 1 Intraorganizational tensions (between individuals or groups within} organizations)
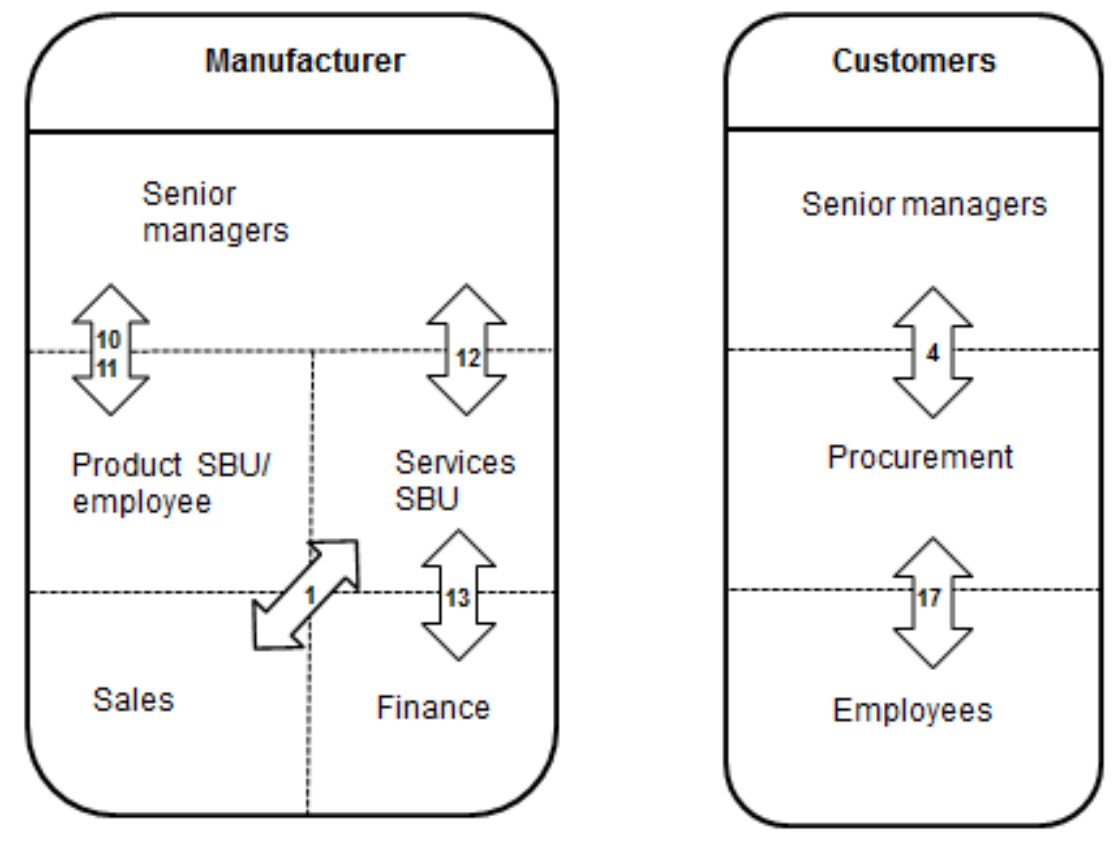

Numbers indicate tensions as listed in Table 1. 
Figure 2: Interorganizational tensions (between actors at different organizations)

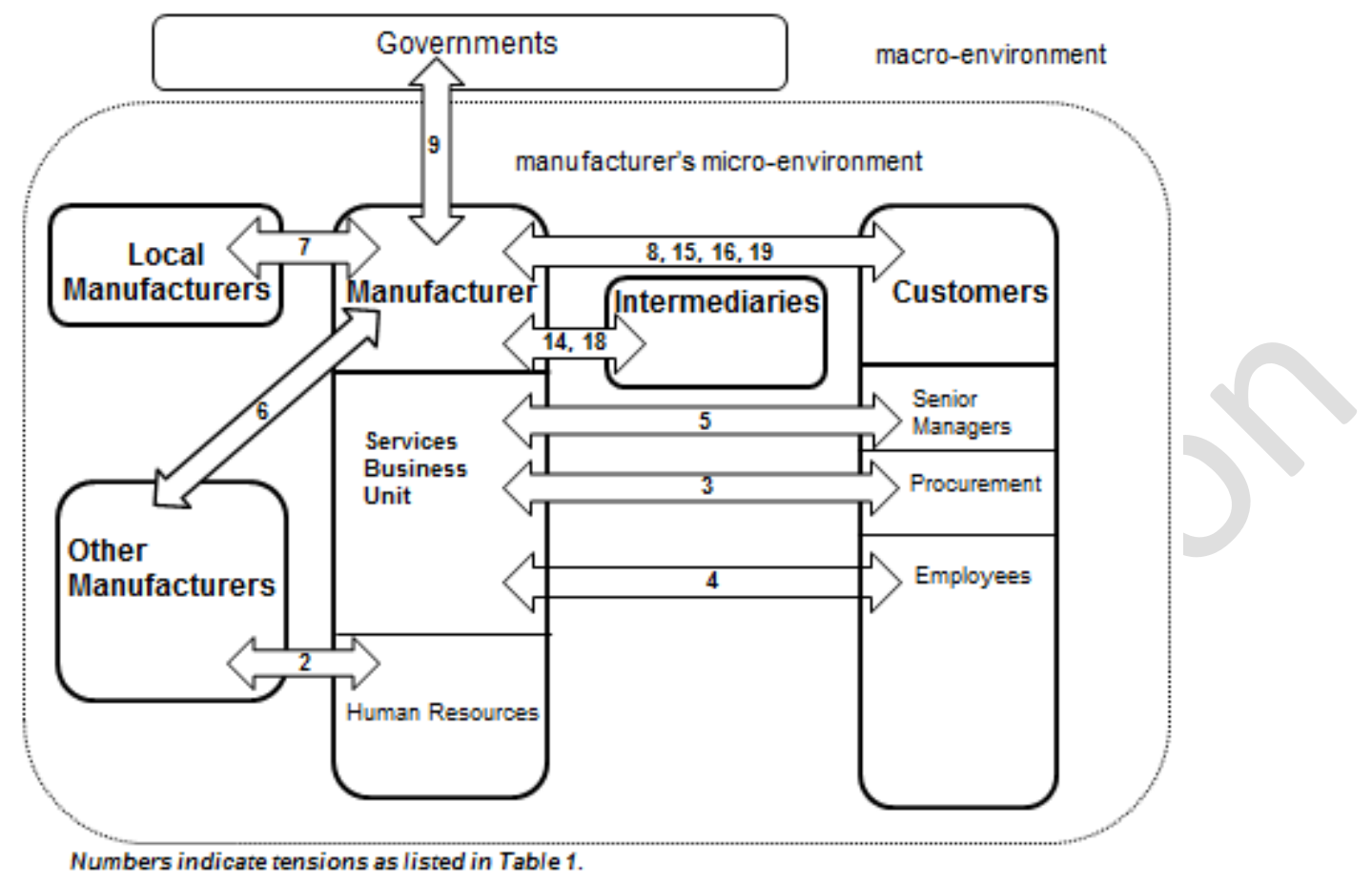

Group I: Direct Challenge to Expertise

Often, the process of servitization requires manufacturers to take ownership of processes or technical domains they had previously left to particular staff members, strategic business units (SBUs), suppliers, intermediaries, competitors, or others. The previous owners of those processes or areas of expertise may feel threatened by this direct challenge to their expertise. To counter the threat, these actors, whether internal or external to the manufacturer, may attempt to resist the manufacturer's attempts to develop more capability within the area of expertise or interfere with the implementation of the new strategy or process. This resistance may take a number of forms. It can be intra-organizational, such as between the product sales team concerned about cannibalizing product markets and the service business unit (tension 1). At ChemCo, for instance, the product sales staff were concerned that customers faced with competition from the manufacturer in the services markets that had previously been left to those customers would cease to buy the manufacturer's products. More commonly, these tensions are interorganizational; for instance, individual managers at customer firms PowerCust and GovCust told us their purchase of services was dependent upon whether they believed they had the capability to service their own equipment; a belief that they could provide their own services more cheaply could lead to resistance to purchasing services (tension 3). Managers at ChemCo described how increased local competition may make local markets, where the company lacks local infrastructure, harder to reach (tension 7). Another source of interorganizational tension is between the manufacturer and government entities, leading to legislative or regulatory barriers to territorial activity (tension 9), the only macro-environmental tension in the list. For instance, ChemCo cited legislation controlling transfer of contaminated products across 
geographical borders as a restriction on business processes and a factor in decisions whether to enter particular geographic spaces.

\section{Group II: Pressure to Learn}

The changes required to shift a manufacturer from product to product-plus-services bring with them a pressure to learn. The implementation of a new strategy or process that firm employees perceive as forcing them to operate in an area beyond their field of experience or develop a new area of expertise can cause internal tension. The manufacturer may face reluctance to abandon an entrenched product culture (tension 10). At PowerCo, for instance, our interviewee reported that tensions arose because experienced manufacturing staff members were accustomed to working with standardized processes and lead times; the variability involved in providing services, such as reconditioning of customer resources, made product-focused workers uncomfortable. PowerCo also faced employee reluctance to acquire new skills to support services (tension 11) — that is, an unwillingness to develop the skills to support new areas of expertise needed to deliver and manage services.

\section{Group III: Cost-Focused Challenges}

A significant cause of tensions within and across organizations was driven by attempts to control costs. These cost-focused challenges were identified as reasons for some actors to resist the changes necessary for a manufacturer to offer services. This group of tensions involved implementation of a strategy, process, or expectation by one actor that a second actor perceived as pressuring or forcing them to enter a market, extend an existing territory, or invest further, which the second actor believes may have a negative impact on their own value creation. Such tensions arose as intra-organizational tensions within the manufacturer, such as between senior managers at ChemCo and service staff, as managers set strategies focused on avoidance of intermediaries' services markets (tension 12) to protect existing supplier relationships, and between finance and service staff at PowerCo, as the finance department's focus on cost control restricted investment within given periods, slowing development of services and creating tensions with service staff (tension 13). Cost-based tensions could also be interorganizational, between manufacturers and intermediaries or suppliers - for example, at TransCo, intermediaries' resistance to demands for increased geographic service coverage (tension 14) —or between manufacturers and customers, as when PowerCust sought to leverage the manufacturer's desire for resource life extension support by demanding increasing levels of supporting services with no corresponding increase in price (tension 15).

\section{Group IV: Process-Change Risk Aversion}

Process-change risk aversion refers to actors perceiving risks associated with implementing the process changes necessary to facilitate servitization. Actor reluctance to influence activities of other actors occurs when actors resist initiating a change because they believe another actor will resist it or will challenge their authority (tension 17). For instance, the EduCust interviewee suggested that younger procurement employees at customer organizations might "lack the stomach" for the internal fight required to get other parts of the organization to adopt external service offerings. Because they are less experienced and have less status than more established employees, they 
might avoid pushing through changes that could open them up to challenges from other staff or threaten their own job security, particularly if the experiment did not go well.

\section{Group V: External Actor Impacts on Value Creation}

The final group of tensions encompasses interorganizational tensions involving actors outside the manufacturer. Such tensions result not from direct challenges to expertise, as in group 1, but instead from concern over failures to engage in the delivery of expertise. External actor impacts on value creation arise from concerns about inconsistent value delivery by an external actor, which reduce a primary actor's ability to deliver consistent services. Manufacturers seeking to dominate a market with services offerings are often subject to dependence on external actor capabilities to succeed in the market (tension 18). Their success is reliant upon the external actor's willingness to cooperate, for example, to provide service logistics infrastructure or technical expertise in delivering subcomponents of a service. For example, distributors for ChemCo provide delivery drivers with expertise in the handling of materials. Similarly, from the other side of the value chain, fluctuations in customer willingness to engage in value co-creation activity can create tensions (tension 19). For instance, GovCust indicated that tensions arose during contract renewal negotiations with a service provider when the company deliberately pulled back from intense cooperation and value co-creation, sharing less insight to ensure parity between competing offers for the contract.

\section{Strategic Responses and Implications for Practice}

Our findings suggest that change associated with servitization efforts is inherently threatening for many actors and that perceived threat, if not addressed, can produce a variety of tensions in the value network. Manufacturers moving toward servitization need to identify where tensions may emerge and act strategically to diffuse them. Identifying an effective course of action requires context-specific knowledge of the threats actors perceive. The scale of response also needs to be at the right level, requiring an understanding of the actors the tension operates between (Table 2). Tensions operating at an organizational level require a comprehensive, holistic response encompassing communication at multiple levels, while responses to tensions involving groups or individuals can be addressed in a more targeted way. 
Table 2.-Possible Responses to Tensions

\begin{tabular}{|c|c|c|c|c|}
\hline Tensions & Actor 1/Scale & Actor 2/Scale & Strategic Response & Example \\
\hline \multicolumn{5}{|c|}{ Group I. Direct Challenge to Expertise } \\
\hline $\begin{array}{l}\text { 1. Fear of cannibalizing } \\
\text { product markets }\end{array}$ & $\begin{array}{l}\text { Manufacturer’s } \\
\text { product sales team } \\
\end{array}$ & $\begin{array}{l}\text { Manufacturer's } \\
\text { service staff or } \\
\text { service SBU }\end{array}$ & $\begin{array}{l}\text { Define targeted metrics to } \\
\text { emphasize importance of } \\
\text { services. }\end{array}$ & $\begin{array}{l}\text { ChemCo set criteria for sales } \\
\text { bonuses so full bonus could } \\
\text { only be achieved if targets } \\
\text { were hit for both products } \\
\text { and services. }\end{array}$ \\
\hline $\begin{array}{l}\text { 2. Competitors poaching } \\
\text { skilled employees }\end{array}$ & $\begin{array}{l}\text { Manufacturer’s } \\
\text { human resources }\end{array}$ & npetitors & $\begin{array}{l}\text { Provide training and career } \\
\text { pipelines to reduce turnover and } \\
\text { maintain deep talent pool. }\end{array}$ & $\begin{array}{l}\text { PECo developed an } \\
\text { apprenticeship program to } \\
\text { develop employees over } \\
\text { time and discourage } \\
\text { turnover. }\end{array}$ \\
\hline $\begin{array}{l}\text { 3. Customer resistance to } \\
\text { purchasing services }\end{array}$ & $\begin{array}{l}\text { Customer's } \\
\text { procurement team } \\
\text { ? }\end{array}$ & $\begin{array}{l}\text { Manufacturer's } \\
\text { SBU }\end{array}$ & $\begin{array}{l}\text { Increase communication about } \\
\text { value of services for customer's } \\
\text { business. Engage in dialogue to } \\
\text { clarify value of offering and } \\
\text { increase transparency around } \\
\text { cost structures, to demonstrate } \\
\text { how service offerings result in } \\
\text { lower real costs. }\end{array}$ & $\begin{array}{l}\text { DefCo engages in dialogue } \\
\text { with potential customers to } \\
\text { explain how its knowledge } \\
\text { and experience can deliver } \\
\text { greater value than the } \\
\text { customer could achieve on } \\
\text { its own, moving the focus } \\
\text { from cost minimization to } \\
\text { value creation. }\end{array}$ \\
\hline $\begin{array}{l}\text { 4. Employee efforts to } \\
\text { protect personal status }\end{array}$ & $\begin{array}{l}\text { Customer's } \\
\text { employees }\end{array}$ & $\begin{array}{l}\text { Customer's } \\
\text { managers } \\
\text { and/or } \\
\text { Manufacturer's } \\
\text { SBU } \\
\end{array}$ & $\begin{array}{l}\text { Engage in transparent } \\
\text { management of customer } \\
\text { expectations regarding value } \\
\text { outcomes. Increase } \\
\text { communication with customer } \\
\text { employees, and emphasize } \\
\text { increased credibility and value } \\
\text { of their new roles with respect to } \\
\text { value co-creation. }\end{array}$ & $\begin{array}{l}\text { EduCust expressed belief } \\
\text { that manufacturers should } \\
\text { help manage customer staff } \\
\text { expectations around } \\
\text { individual employee } \\
\text { outcomes of servitization. }\end{array}$ \\
\hline
\end{tabular}




\begin{tabular}{|c|c|c|c|c|c|}
\hline & Fear of expertise loss & $\begin{array}{l}\text { Customer's senior } \\
\text { managers } \\
\text { (-) }\end{array}$ & $\begin{array}{l}\text { Manufacturer's } \\
\text { SBU } \\
\Delta\end{array}$ & $\begin{array}{l}\text { Communicate with customer } \\
\text { managers around desired end } \\
\text { states in terms of retained skill- } \\
\text { sets. }\end{array}$ & $\begin{array}{l}\text { The EduCust manager } \\
\text { argued that customers can } \\
\text { lose critical skill-sets during } \\
\text { servitization and suggested } \\
\text { that servitization agreements } \\
\text { should define the customer's } \\
\text { desired capability retention } \\
\text { post servitization. }\end{array}$ \\
\hline & $\begin{array}{l}\text { Increased competition } \\
\text { in product and services } \\
\text { markets }\end{array}$ & $\begin{array}{l}\text { Manufacturer } \\
\text { P }\end{array}$ & & $\begin{array}{l}\text { Use technology to remotely } \\
\text { service resources in customer } \\
\text { locations to provide value via } \\
\text { preventative servicing. }\end{array}$ & \multirow{2}{*}{$\begin{array}{l}\text { ChemCo developed mobile } \\
\text { capabilities and joint } \\
\text { ventures. PowerCo } \\
\text { recommended using } \\
\text { internationally consistent } \\
\text { components for service } \\
\text { solutions. PowerCo, PECo, } \\
\text { and GovOrg recommended } \\
\text { the use of remote predictive } \\
\text { monitoring technology to } \\
\text { provide breakdown } \\
\text { prevention. }\end{array}$} \\
\hline & $\begin{array}{l}\text { Increased local } \\
\text { competition }\end{array}$ & $\begin{array}{l}\text { Manufacturer } \\
\text { מ゙ }\end{array}$ & & $\begin{array}{l}\text { Manufacturer work with partners } \\
\text { to increase size of service } \\
\text { network. Standardize resources } \\
\text { \& exploit technology to } \\
\text { remotely serve. }\end{array}$ & \\
\hline & $\begin{array}{l}\text { Customer pressure for } \\
\text { skills transfer }\end{array}$ & Manufacturer & & $\begin{array}{l}\text { Customers demand that } \\
\text { manufacturers share knowledge } \\
\text { about product servicing so that } \\
\text { they can self-serve rather than } \\
\text { relying on service provision. }\end{array}$ & $\begin{array}{l}\text { DefCo now trains customers } \\
\text { to service resources they } \\
\text { buy, while innovating to } \\
\text { create new innovative } \\
\text { services and processes. }\end{array}$ \\
\hline & $\begin{array}{l}\text { Legislative/regulatory } \\
\text { barriers to territorial } \\
\text { activity }\end{array}$ & Manufacturer & Government(s) & $\begin{array}{l}\text { Invest in a multilocation, } \\
\text { multifeature infrastructure to } \\
\text { allow flexible response to } \\
\text { governmental barriers. }\end{array}$ & $\begin{array}{l}\text { ChemCo invests in } \\
\text { developing physical resource } \\
\text { capabilities within every } \\
\text { market in which it operates. }\end{array}$ \\
\hline
\end{tabular}




\begin{tabular}{|c|c|c|c|c|}
\hline \multicolumn{5}{|l|}{ Group II: Pressure to Learn } \\
\hline $\begin{array}{l}\text { 10. Reluctance to abandon } \\
\text { entrenched product } \\
\text { culture }\end{array}$ & $\begin{array}{l}\text { Manufacturer's } \\
\text { employee } \\
\text { ? }\end{array}$ & $\begin{array}{l}\text { Manufacturer's } \\
\text { manager } \\
\end{array}$ & $\begin{array}{l}\text { Identify and appoint service } \\
\text { champions to encourage peers to } \\
\text { engage with service activities }\end{array}$ & $\begin{array}{l}\text { PowerCo identifies service } \\
\text { champions with } \\
\text { manufacturing experience to } \\
\text { act as bridges between } \\
\text { product manufacturing and } \\
\text { services staff, encouraging } \\
\text { product-focused employees } \\
\text { to be more flexible. }\end{array}$ \\
\hline $\begin{array}{l}\text { 11. Employee reluctance to } \\
\text { acquire new skills to } \\
\text { support services }\end{array}$ & $\begin{array}{l}\text { Manufacturer's } \\
\text { employee } \\
\text { ? }\end{array}$ & $\begin{array}{l}\text { Manufacturer's } \\
\text { manager } \\
\text { ? }\end{array}$ & $\begin{array}{l}\text { Encourage employees to acquire } \\
\text { new service-related skills and } \\
\text { support employee learning. }\end{array}$ & $\begin{array}{l}\text { PowerCo initiated a training } \\
\text { program to help employees } \\
\text { acquire needed skills. }\end{array}$ \\
\hline
\end{tabular}




\begin{tabular}{|c|c|c|c|c|}
\hline \multicolumn{5}{|c|}{ Group III: Cost-Focused Challenges } \\
\hline $\begin{array}{l}\text { 12. Managers' avoidance of } \\
\text { intermediaries' services } \\
\text { markets for strategic } \\
\text { reasons. }\end{array}$ & $\begin{array}{l}\text { Manufacturer’s } \\
\text { senior managers } \\
\Theta\end{array}$ & $\begin{array}{l}\text { Manufacturer's } \\
\text { service staff or } \\
\text { service SBU }\end{array}$ & $\begin{array}{l}\text { Educate senior managers to } \\
\text { balance decision making, } \\
\text { assessing potential loss of } \\
\text { existing markets and } \\
\text { relationships versus potential } \\
\text { gains from new services } \\
\text { markets. }\end{array}$ & $\begin{array}{l}\text { ChemCo's service director } \\
\text { works to influence strategic } \\
\text { decision makers to consider } \\
\text { the opportunity cost of } \\
\text { protecting existing } \\
\text { relationships versus the } \\
\text { potential value of long-term } \\
\text { services opportunities. }\end{array}$ \\
\hline 13. Focus on cost control & $\begin{array}{l}\text { Manufacturer’s } \\
\text { finance employees } \\
0\end{array}$ & $\begin{array}{l}\text { Manufacturer's } \\
\text { service staff or } \\
\text { service SBU } \\
\end{array}$ & $\begin{array}{l}\text { Educate finance staff about the } \\
\text { longer-term nature of value } \\
\text { creation opportunities from } \\
\text { services. }\end{array}$ & $\begin{array}{l}\text { TransCo trains its finance } \\
\text { staff in through-life pricing. } \\
\text { DefCo developed in its } \\
\text { finance department the } \\
\text { capability to assess risk and } \\
\text { set services pricing. }\end{array}$ \\
\hline $\begin{array}{l}\text { 14. Resistance to } \\
\text { manufacturer demands } \\
\text { for increased } \\
\text { geographic coverage }\end{array}$ & Manufacturer & & $\begin{array}{l}\text { Manufacturers work with their } \\
\text { intermediaries and suppliers to } \\
\text { enable them to develop new } \\
\text { services so that together they can } \\
\text { provide a more comprehensive } \\
\text { service network to support } \\
\text { integrated advanced services } \\
\text { offerings. }\end{array}$ & $\begin{array}{l}\text { The Intermediary TransInt } \\
\text { entered into third-party } \\
\text { agreements to deliver the } \\
\text { geographic service networks } \\
\text { required by its manufacturer } \\
\text { partner. }\end{array}$ \\
\hline $\begin{array}{l}\text { 15. Customer demand for } \\
\text { life extension support }\end{array}$ & Manufacturer & Customer & $\begin{array}{l}\text { As equipment ages, in order to } \\
\text { extend the product life cycle, } \\
\text { manufactures will share costs of } \\
\text { maintaining product } \\
\text { infrastructure in order to retain a } \\
\text { service contract and perhaps } \\
\text { even avoid the customer from } \\
\text { shutting down the infrastructure. }\end{array}$ & $\begin{array}{l}\text { The manufacturer supplying } \\
\text { product infrastructure to } \\
\text { PowerCust extended the } \\
\text { maintenance contract to } \\
\text { allow the product to be used } \\
\text { for longer than normally } \\
\text { recommended. }\end{array}$ \\
\hline $\begin{array}{l}\text { 16. Interference of existing } \\
\text { systems with new } \\
\text { services purchases }\end{array}$ & Customer & Manufacturer & $\begin{array}{l}\text { Design back-compatible } \\
\text { flexibility into new } \\
\text { technological service solutions. }\end{array}$ & $\begin{array}{l}\text { GovCust suggested that their } \\
\text { supplier would need to } \\
\text { supply flexible solutions that } \\
\text { are back-compatible with }\end{array}$ \\
\hline
\end{tabular}




\begin{tabular}{|c|c|c|c|c|}
\hline & & & & older IT systems. \\
\hline \multicolumn{5}{|c|}{ Group IV: Process-Change Risk Aversion } \\
\hline $\begin{array}{l}\text { 17. Actor reluctance to } \\
\text { influence activities of } \\
\text { other actors }\end{array}$ & $\begin{array}{l}\text { Customer’s } \\
\text { procurement } \\
\text { employee } \\
\text { ? }\end{array}$ & $\begin{array}{l}\text { Customer's } \\
\text { employees }\end{array}$ & $\begin{array}{l}\text { Educate HR departments } \\
\text { about the potential risks of } \\
\text { employing risk-averse staff. }\end{array}$ & $\begin{array}{l}\text { The EduCust manager } \\
\text { suggested that manufacturers } \\
\text { should discuss this risk with } \\
\text { customer HR teams. }\end{array}$ \\
\hline \multicolumn{5}{|c|}{ Group V: External Actor Impacts on Value Created } \\
\hline $\begin{array}{l}\text { 18. Dependence on third- } \\
\text { party capabilities to } \\
\text { succeed in market }\end{array}$ & Manufacturer & Intermediary & $\begin{array}{l}\text { Develop relationships with } \\
\text { third parties to secure } \\
\text { needed performance to } \\
\text { support service delivery. }\end{array}$ & $\begin{array}{l}\text { ChemCo works to develop } \\
\text { closer relationships with } \\
\text { intermediaries, involving } \\
\text { them at every stage of } \\
\text { services design. }\end{array}$ \\
\hline $\begin{array}{l}\text { 19. Fluctuations in } \\
\text { customer willingness to } \\
\text { engage in value co- } \\
\text { creation activity }\end{array}$ & Manufacturer & Customer & $\begin{array}{l}\text { Invest time and effort to } \\
\text { compensate for customers' } \\
\text { periodic reduction in } \\
\text { engagement in order to } \\
\text { ensure maintenance of } \\
\text { service delivery standards } \\
\text { and minimize impact on } \\
\text { value creation. }\end{array}$ & $\begin{array}{l}\text { GovCust reduces } \\
\text { information flows to } \\
\text { manufacturers during } \\
\text { contract tender periods, } \\
\text { reducing opportunities for } \\
\text { co-creation of value. DefCo } \\
\text { ensure they interact more } \\
\text { frequently in other periods. }\end{array}$ \\
\hline
\end{tabular}


Responses or proactive efforts to defuse tension may take a range of forms, from tailored investment or new processes and metrics to transparent communication, innovation sharing, and targeted remuneration. For instance, PECo responded to the potential poaching of skilled employees by investing in employee training and other mechanisms to ensure access to a deep reserve of talent and secure succession planning; one element of this plan was an apprenticeship program that took on up to five new people per year. ChemCo's response to internal tension created by product sales staff concerns about cannibalization of product markets was to set combined product and service sales targets, with sales team members only receiving full bonuses if they hit both targets. This new metric encouraged the sales team to see sales of products and services as equally important. ChemCo also responded to tensions in this group with investment; in several geographical markets, the company invested in costly infrastructure in response to regulatory acts restricting the transfer of contaminated materials across geographical borders. A number of manufacturers recommended use of remote predictive monitoring technology to provide breakdown prevention; these sophisticated systems create competitive advantage, because smaller local suppliers may not be able to offer them.

Dealing with tensions between actors at any combination of individual, group, or organizational levels requires strategic responses and communication customized at the correct level. For example, tensions can exist between individuals, such as between individual employees of the manufacturer and the manufacturer's manager, for instance if the employers are reluctant to abandon the organization's entrenched product culture. In this instance, it is important that the manufacturer acts to address the underlying problem with the culture and finds a way to communicate effectively with individual employees. For example, PowerCo's response was to deploy service champions-particular employees engaged with the service delivery process who were capable of acting as advocates to convince others to also engage.

Tensions can also exist between individuals and groups of employees, such as when finance staff act to prevent new investment in service initiatives. Facing this issue, both TransCo and DefCo recognized the need to retrain finance-related staff members, to give them the skills to recognize the long-term value opportunities presented by services and the ability to work with service SBU staff in pricing services. Tensions may also develop between two groups of actors, such as when entire product sales teams resist the new strategies imposed by service SBUs. ChemCo addressed this tension by developing a new lever to change the behavior of its product sales team-a new bonus system that incorporated both service and product sales targets.

Tensions may also arise between groups of actors at one organization and other entire organizations, such as when competitors poach skilled service employees, leading to tensions between the manufacturer's HR team and the competitor organization. PECo responded to this problem with an internal solution - an apprenticeship program designed to engage and reward employees over time. This approach suggests that it is perhaps easier to influence an internal group of actors than to confront an external organization.

Finally, tensions may arise between organizations, such as when DefCo's customers started to demand that the manufacture share knowledge to allow the customers to reduce 
their dependency on DefCo. Acquiescing to this demand would obviously reduce DefCo's revenue from servitized offerings. However, this is exactly what the company chose to do in order to retain customers. The company balanced customer demands against its strategic needs by being careful to give away only older knowledge while at the same time investing in service development to ensure an ongoing stream of innovation to sustain future services revenue streams. This action is similar to decisions ChemCo made, in response to increased competition in services markets, to develop mobile operational capabilities that allow the company to deliver services at customer sites and joint ventures. These examples suggest that organizational tensions are perhaps more likely to lead to defensive investment by the actors facing them rather than strategic responses designed to change the behavior of other actors.

\section{Conclusion}

Firms engaged in service innovation need to move beyond merely transforming their own organization to developing a better understanding of customers' needs and sources of value creation (Parida et al. 2014). Often, achieving servitization requires integrating the contributions of a network of actors, from component suppliers to intermediaries to customers, to create new sources of value. But as the servitization process moves forward, and the manufacturer moves to take over new areas of expertise or shed old mind sets and processes, the changes can generate tensions in the value network, undermining the needed integration. Succeeding at servitization means recognizing those tensions and acting to address them.

Thus, identifying and reducing tensions should be a priority for firms engaged in service innovation. Manufacturers should recognize that as they expand operations into services, and engage in new activities that overlap with the established domains of other actors, they will face tensions with those other actors. Those tensions can be addressed through a wide range of actions. At the same time, in order to benefit from value gains from servitization, manufacturers may need to develop and wield greater power in the value chain, moving into areas of expertise previously occupied by other network actors. In these situations, focusing efforts on value co-creation, increasing the transparency of operations, and engaging more closely with suppliers, intermediaries, and customers can help ameliorate tensions. Where tensions are unavoidable but damaging to value creation, rapid domination through assertive action can reduce the longevity of tension, thus reducing value loss.

Thus, there is a need for managers to recognize that servitization is not a process that can be achieved by a manufacturer alone without consideration of, and preparation for, the likely responses of other actors in its network. Organizations involved in servitization must consider mechanisms to reduce the scope, size, and longevity of tensions emerging as a result of the introduction of new activities and processes. Managers need to learn to manage tensions at varying levels across their organizations' networks if they wish to achieve strong performance outcomes from their servitization efforts. 


\section{References}

Baines, T. S., and Lightfoot, H. 2013. Made to Serve: Understanding What It Takes for a Manufacturer to Compete Through Servitization and Product-Service Systems. Hoboken, NJ: Wiley.

Baines, T. S., Lightfoot, H., Benedettini, O., and Kay, J. 2009. The servitization of manufacturing: A review of literature and reflection on future challenges. Journal of Manufacturing Technology Management 20(5): 547-567.

Davies, A., Brady, T., and Hobday, M. 2007. Organizing for solutions: Systems seller vs. systems integrator. Industrial Marketing Management 36(2): 183-193.

Gertler, M. S. 1995. "Being there”: Proximity, organization, and culture in the development and adoption of advanced manufacturing technologies. Economic Geography 71(1): 1-26.

King, N. 2004. Using templates in the thematic analysis of text. In Essential Guide to Qualitative Methods in Organizational Research, edited by C. Cassell and G. Symon, 256-270. London: Sage.

Kowalkowski, C., Kindström, D., and Witell, L. 2011. Internalisation or externalisation? Examining organizational arrangements for industrial services. Managing Service Quality: An International Journal 21(4): 373-391.

Oliva, R., and Kallenberg, R. 2003. Managing the transition from products to services. International Journal of Service Industry Management 14(2): 160-172.

Paiola, M., Saccani, N., Perona, M., and Gebauer, H. 2013. Moving from products to solutions: Strategic approaches for developing capabilities. European Management Journal 31(4): 390-409.

Parida, V., Sjödin, D. R., Wincent, J., and Kohtamäki, M. 2014. Mastering the transition to product-service provision: Insight into business models, learning activities, and capabilities. Research-Technology Management 57(3): 44-52.

Raddats, C. O., and Burton, J. 2014. Creating multi-vendor solutions: The resources and capabilities required. Journal of Business and Industrial Marketing 29(2): 132142.

Reinartz, W., and Ulaga, W. 2008. How to sell services more profitably. Harvard Business Review 86(5): 90-96.

Salonen, A. and Jaakkola, E. 2015. Firm boundary decisions in solution business: Examining internal vs. external resource integration. Industrial Marketing Management 51: 171-183.

Spring, M., and Araujo, L. 2013. Beyond the service factory: Service innovation in manufacturing supply networks. Industrial Marketing Management 42(1): 59-70 
Story, V., Raddats, C., Burton, J., Zolkiewski, J., and Baines, T., 2016. Capabilities for advanced services: A multi-actor perspective. Industrial Marketing Management. Published electronically May 9.

http://dx.doi.org/10.1016/j.indmarman.2016.04.015

Tukker, A. 2004. Eight types of product-service system: Eight ways to sustainability? Experiences from SusProNet. Business Strategy and the Environment 13(4): 246260.

Zolkiewski, J., Burton, J., and Stratoudaki, S. 2008. The delicate power balance in advertising agency-client relationships: Partnerships or battleground? The case of the Greek advertising market. Journal of Customer Behaviour 7(4): 315-332. 